\title{
Comparative Study of Pollen Grains Morphology and Phytochemical Constituents of Some Saudi Arabian Date Palm (Phoenix dactylifera L.) Cultivars
}

Hanan Mahmoud Abou-Zeid ${ }^{1 *}$, Mona Adel Shiha ${ }^{2}$ and Azza Ahmed Shehata ${ }^{1}$

${ }^{1}$ Botany \& Microbiology Department, Faculty of Science, Alexandria University, Egypt

${ }^{2}$ Department of Biology and Geology, Faculty of Education, Alexandria University, Egypt

*Corresponding author

Keywords

Antioxidant activity, Flavonoids, Phenolics, Pollen grains

Article Info

Accepted:

26 June 2019

Available Online:

10 July 2019

A B S T R A C T

Pollen morphological and phytochemical comparative study of nine Saudi Arabian date palm (Phoenix dactylifera L.) cultivars has been carried out. Pollen grains are generally small in size, monad, hetero-polar, asymmetric, elliptic in equatorial view, mono-sulcate. Exine sculpturing is micro-reticulate. Little differences have shown in the pollen dimensions, muri thickness and lumen size. The phytochemical screening of date palm pollen grains revealed the presence of high amounts of phenolics and flavonoids and displayed good antioxidant capacity. Additionally, High performance liquid chromatography (HPLC) analysis showed noticeable valuations in the distribution of different phenolic compounds among the nine pollen samples compared with 14 reference standards. Gallic acid, chlorogenic acid and caffeic acid were commonly detected in all methanolic pollen extracts. Moreover, 2, 5- dihydroxy benzoic acid and cinnamic acid are not detected in any of pollen samples. Pollen grains phytochemical screening beside their morphology may have a prospect value in the characterization of the studied Saudi Arabian male date palm cultivars. These results revealed that date palm pollen has antioxidant properties that could play a major role in human health and could provide dietary alternatives.

\section{Introduction}

Phoenix dactylifera L. is a monocotyledonous, dioecious, perennial tree belonging to Arecaceae -subfamily Coryphoideae- tribe Phoeniceae (Eoin, 2016). Nearly 3000 cultivars are distributed around the world (Zaid and De Wet, 1999). Cultivation of date palm trees has a very significant impact on the history of the ancient Middle East civilization. Date palm is an important fruit crop grown in the arid regions of Africa, Middle East and South Asia. Saudi Arabia is one of the leading date producing countries that cultivate about 400 cultivars (Bashah et al., 1997). The entire tree of date palm is employed to provide food, shelter, fiber, furniture and many other products. Moreover, the date palm tree 
successfully tolerates extremely adverse environmental conditions including drought, high temperature and salinity, which are the common criteria of desert lands. Date palm pollen grains (DPP) are a good economic and essential nutritional source becoming thus an excellent food supplements (Hassan, 2011 and Bishr and El-Desouky, 2012). DPP are also used as folk medicine. Regular consumption is beneficial in nephropathy, rheumatism, gastropathy and sexual debility (Elginidi et al., 2015). Many other therapeutic properties for DPP extracts have been studied as an antioxidant and antimicrobial agents (Bassuny et al., 2013 and Farouk et al., 2015). More recently, Najla et al., (2017), identified some bioactive compounds extracted from date palm seeds and pollen, and evaluated their antibacterial and antifungal properties. Accordingly, chemical components of DPP have gained a lot of attention in order to find out the main constituents responsible for such activities. Morphological characters of the female tree are usually taken into consideration for cultivar identification. However, the male trees identification is a difficult process because they are mostly identical to any female cultivar. However, farmers dealing with date palms can identify some male cultivars from their experience (Simozarg et al., 2016).

Morphological characteristics of pollen grains can be useful characters in taxonomic studies because many pollen traits are influenced by the strong selective forces involved in various reproductive processes, including pollination, dispersal, and germination (Erdtman, 1952). In the meantime use of pollen morphology solely as a taxonomic character is challenging, and pollen characteristics must be considered in concert with other characteristics. Accordingly, the current study has been conducted to characterize the pollen morphology of nine cultivars of date palms grown in Saudi Arabia as well as detect and analyze their phytochemical constitution aiming to develop an additional pollen identification tools and to determine the antioxidant activity based on their total phenolics and flavonoids content, as well as on the content of individual phenolic compounds.

\section{Materials and Methods}

Pollen grains of nine date palm cultivars were obtained from Faculty of Food Science and Agriculture, King Saud University, Riyadh, Saudi Arabia. Pollen grains were examined using both light microscope (LM) and scanning electron microscope (SEM). Samples for LM examination were mounted on slides using glycerol jelly and observed under a Zeiss microscope. For SEM analysis, dried pollen grains were placed on copper stubs using double sided adhesive tape and coated with gold in a polaron JEC-1100E coating unit, then scanned and photographed with JEOL JSM-5300 SEM at Electron Microscope Unit - Faculty of Science - Alexandria University - Egypt. All measurements were based on 20 readings from each cultivar by using Image Tools software with high accuracy and the following parameters were recorded: pollen length, pollen width, colpus length, muri thickness and lumen area were measured. The terminology followed here is that of Erdtman (1952) and Punt et al., (2007).

\section{Phytochemistry of pollen grains}

\section{Preparation of extracts}

The pollen samples (each $3 \mathrm{~g}$ ) were individually extracted with $100 \mathrm{~mL}$ of methanol kept on a rotary shaker for $24 \mathrm{~h}$. Thereafter, it was filtered and centrifuged at $5000 \mathrm{~g}$ for $15 \mathrm{~min}$. The supernatant was collected and the solvent was evaporated to make the final volume one-fifth of the original volume (Tura and Robards, 2002). It was 
stored at $4{ }^{\circ} \mathrm{C}$ in air tight bottles for further studies.

\section{Determination of total phenolic content}

The total phenolic content was determined with the Folin-Ciocalteu method (Wolfe et al., 2003). The reaction mixture contained $200 \mu \mathrm{L}$ of pollen methanolic extract, $800 \mu \mathrm{L}$ of freshly prepared diluted Folin- Ciocalteu reagent and $2 \mathrm{ml}$ of $7.5 \%$ sodium carbonate. The final mixture was diluted to $7 \mathrm{~mL}$ with deionized water. Mixtures were kept in dark at ambient conditions for $2 \mathrm{~h}$ to complete the reaction. Absorbance of samples and standard were measured at $765 \mathrm{~nm}$ using a T80 UV-Vis spectrophotometer - double beam. Total phenolic content was expressed as gallic acid ( $\left.\mathrm{mg} \mathrm{g}^{-1} \mathrm{DW}\right)$.

\section{Determination of total flavonoid content}

Total flavonoid content in the pollen extracts was estimated by the aluminum chloride, colorimetric assay method reported by Potter et al., (2010). A volume of $0.5 \mathrm{ml}$ of $2 \% \mathrm{AlCl}_{3}$ ethanol solution was added to $0.5 \mathrm{~mL}$ of sample methanolic extract. After one hour at room temperature, the absorbance was measured at $420 \mathrm{~nm}$ using a T80 UV-Vis spectrophotometer-double beam. Total flavonoid content was calculated as rutin (mg g $\left.{ }^{-1} \mathrm{DW}\right)$.

\section{DPPH free radical scavenging activity}

Radical scavenging activity of pollen extracts against stable 2, 2diphenyl 2 picrylhydrazyl hydrate (DPPH) was determined by the method of Singh et al., (2002). The change in colour was measured at $517 \mathrm{~nm}$ on a T80 UV$\mathrm{V}$ is spectrometer, double beam. One $\mathrm{mL}$ of aliquots of the extract $\left(20-100 \mu \mathrm{g} \mathrm{mL}^{-1}\right)$ was added to methanol solution of DPPH $(5 \mathrm{~mL}$, $0.1 \mathrm{mM}$ ) and vortexed. The samples were kept in the dark for 20 minutes at room temperature and the decrease in absorbance was measured at $517 \mathrm{~nm}$ against a blank. The results were expressed as $\mathrm{EC}_{50}$, which means the minimum concentration required for the antioxidant to reduce the initial concentration of the DPPH radicals by $50 \%$. Radical scavenging activity was calculated by the following formula: $\%$ Inhibition $=\left[\left(A_{B}-A_{A}\right) / A_{B}\right] \times 100$ Where $A_{B}=$ absorption of blank sample, $\mathrm{A}_{\mathrm{A}}=$ absorption of test extract solution.

\section{HPLC analysis}

Isolation and quantification of individual phenolic compounds were obtained using a reversed-phase HPLC method described by Padda and Picha (2007). Twenty micro litter sample extract analyzed with a Exclipse XDB $\mathrm{C}_{18}(5 \mu \mathrm{m}, 4.6 \times 150 \mathrm{~mm})$ column using a mobile phase consisting of $1 \%(\mathrm{v} / \mathrm{v})$ formic acid in aqueous solution: acetonitrile: 2propanol (70:22:8), $\mathrm{pH} 2.5$; flow rate: 0.75 $\mathrm{mL} / \mathrm{min}$, temperature: $30{ }^{\circ} \mathrm{C}$, UV detection at $320 \mathrm{~nm}$ : Agilent technologies 1200 series. Identification and peak assignment of the compound was based on comparison of its retention time with corresponding standard and by spiking of sample with the standard. Quantification of the compound was done using total peak area and each peak with external standard.

\section{Statistical analysis}

Statistical analysis was performed using Stat View 5.0 software. The phytochemical results were reported as the average of three repetitions $\pm \mathrm{SE}$ (standard error).

\section{Results and Discussion}

General pollen grains characteristics (Table 1 and Figures 1 \&2)

Identifying a particular cultivar is difficult because there are not reliable biological and 
biochemical markers as well as the environmental factors that may affect the phenotype (Martínez-Gómez et al., 2005). For the identification of cultivars, macromorphological characters such as leaf, flower, and fruit parameters are utilized. Complement to these characters, the micromorphological characteristics of the pollen grains are one of the most important and valuable parameters for solving controversial taxonomical problems and distinguishing species and cultivars of fruit trees (Nikolić and Milatović, 2016).

The present study revealed that pollen morphology of date palm cultivars appeared to be relatively uniform. Regarding outline pollen grain elliptic in equatorial view, mean lengths of pollen grain ranged from 16.3 $18.17 \mu \mathrm{m}$ whereas pollen width was 11.17$12.37 \mu \mathrm{m}$. Based on the pollen length, the smallest mean pollen size recorded in cultivar Dikhiny $(16.3 \mu \mathrm{m})$ while the largest size of pollen $(18.17 \mu \mathrm{m})$ was recorded in cultivar Safawy. Pollen grains are mono sulcate, aperture extending almost the full length of the grain axis.

Aperture membrane is smooth, thin and narrow with inconspicuous margin. The present finding agreed with results of Soliman and Al-Obeed (2013) as well as Mohamed et al., (2016). They observed almost the same pollen morphological characters within Saudi Arabian date palm cultivars. The exine sculpturing of all investigated cultivars is micro-reticulate, with simpli to duplibaculated muri. The mean muri thickness ranged from $0.08 \mu \mathrm{m}$ to $0.16 \mu \mathrm{m}$. The most thickened muri $(0.16 \mu \mathrm{m})$ was recorded in cultivar Sallag, whereas the thinnest one in cultivar Safry. Moreover, lumen sizes and shapes revealed differences among the studied cultivars. Cultivar Safry, showed the widest lumen (0.53 $\mu \mathrm{m})$ while the narrowest $(0.02 \mu \mathrm{m})$ is recorded in cultivar Khalas. Generally, the pollen features of the studied cultivars agreed with the previous observations of several workers (e.g. Erdtman, 1969; Harley, 1990; Rashid et al., 2017). They mentioned that the monosulcate pollen type with reticulate to micro reticulate tectum occurred throughout the entire family Palmae.

\section{Phytochemical analysis (Table 2 and Figures 3\&4)}

Date pollen cultivars, are recognized as an important source of compounds with pharmacological properties (Morais et al., 2011). Chemical analysis of pollen grains has revealed the presence of a wide range of biochemically and nutritionally important substances (Almeida- Muradian et al., 2005).

Phenolic compounds are plant secondary metabolites and a class of antioxidant agents that include flavonoids, stilbenes, coumarins, and phenolic acids (Tulipani et al., 2008). In the present study, the phytochemical screening of the methanolic extracts of nine palm pollen grains cultivars were performed. Pollen extracts showed high amounts of phenolics and flavonoids content. The maximum values of phenolics were recorded in cultivars Safawy and Safry while Khadary and Safawy showed maximum flavonoids (Figure 3A).

The DPPH radical scavenging assay is used for the screening and evaluation of the antioxidants activity. Substances which are able to perform this reaction can be considered as antioxidants and therefore radical scavengers (Zou and Wei, 2004 and Moreria et al., 2008). The $\mathrm{EC}_{50}$ values of scavenging activities on DPPH radical in pollen extracts were illustrated in Figure 3B. This activity might be related to the nature of phenolic and flavonoids, thus, contributing to their electron transfer/hydrogen donating ability. Similar results were reported by Kumazawa et al., (2004) and Czapecka et al., (2005). 
Table.1 General pollen features of the examined Phoenix dactylifera cultivars

\begin{tabular}{|c|c|c|c|c|c|c|c|}
\hline No. & Characters & \multicolumn{5}{|c|}{ Mean $(\mathbf{\mu m})$} & \multirow{2}{*}{ Tectum } \\
\cline { 2 - 7 } & Cultivars & $\begin{array}{c}\text { Pollen } \\
\text { length }\end{array}$ & $\begin{array}{c}\text { Pollen } \\
\text { width }\end{array}$ & $\begin{array}{c}\text { Colpus } \\
\text { length }\end{array}$ & $\begin{array}{c}\text { Muri } \\
\text { thickness }\end{array}$ & $\begin{array}{c}\text { Lumina } \\
\text { size }\end{array}$ & \\
\hline $\mathbf{1}$ & Mabroom & 17.12 & 11.55 & 16.8 & 0.14 & 0.08 & Micro reticulate \\
\hline $\mathbf{2}$ & Sallag & 17.28 & 11.88 & 17.0 & 0.16 & 0.09 & Micro reticulate \\
\hline $\mathbf{3}$ & Khadary & 17.20 & 11.92 & 16.5 & 0.15 & 0.20 & Micro reticulate \\
\hline $\mathbf{4}$ & Dikhiny & 16.3 & 11.17 & 16.0 & 0.11 & 0.25 & Micro reticulate \\
\hline $\mathbf{5}$ & Maktumi & 16.83 & 12.37 & 15.9 & 0.09 & 0.21 & Micro reticulate \\
\hline $\mathbf{6}$ & Succary & 18.0 & 12.25 & 17.5 & 0.11 & 0.30 & Micro reticulate \\
\hline $\mathbf{7}$ & Safawy & 18.17 & 12.27 & 18.0 & 0.09 & 0.11 & Micro reticulate \\
\hline $\mathbf{8}$ & Khalas & 17.82 & 12.29 & 17.1 & 0.10 & 0.02 & Micro reticulate \\
\hline $\mathbf{9}$ & Safry & 17.58 & 12.07 & 16.98 & 0.08 & 0.53 & Micro reticulate \\
\hline
\end{tabular}

Table. 2 HPLC analyses of phenolics constituents of the methanolic extracts of the nine pollen cultivars 1-9, names of cultivars are in Table 1

\begin{tabular}{|c|c|c|c|c|c|c|c|c|c|}
\hline \multirow[t]{2}{*}{ Peak Name } & \multicolumn{9}{|c|}{ Amount ( $\left.\mu \mathrm{g} \mathrm{mL} \mathbf{L}^{-1}\right)$} \\
\hline & 1 & 2 & 3 & 4 & 5 & 6 & 7 & 8 & 9 \\
\hline Gallic acid & 8.21 & 2.60 & 1.80 & 2.93 & 4.08 & 2.36 & 1.85 & 1.48 & 1.46 \\
\hline Chlorogenic acid & 60.17 & 41.32 & 33.28 & 63.01 & 25.18 & 1.55 & 130.05 & 42.89 & 128.90 \\
\hline Caffeic acid & 68.83 & 72.20 & 29.43 & 72.69 & 26.13 & 34.38 & 127.74 & 52.72 & 187.25 \\
\hline $\begin{array}{l}\text { 3, 4- Dicaffeoyl quinic } \\
\text { acid }\end{array}$ & - & - & 16.72 & - & 6.16 & 27.06 & 25.17 & - & - \\
\hline $\begin{array}{l}\text { 2, 5- Dihydroxy } \\
\text { benzoic acid }\end{array}$ & - & - & - & - & - & - & - & - & - \\
\hline $\begin{array}{l}\text { 3, 5- Dicaffeoyl quinic } \\
\text { acid }\end{array}$ & - & - & - & - & - & 9.30 & - & - & - \\
\hline $\begin{array}{l}\text { 4, 5-Dicaffeoyl quinic } \\
\text { acid }\end{array}$ & 7.15 & 10.21 & 3.83 & 5.32 & 3.16 & 8.19 & 19.01 & - & 12.15 \\
\hline Catechin & - & - & - & - & 22.27 & - & - & 50.84 & - \\
\hline Rutin & - & - & 2.29 & 2.72 & 1.69 & 5.52 & 2.50 & 4.40 & 5.52 \\
\hline Phloridzin & - & 1.51 & 2.43 & 1.80 & - & 2.07 & 3.57 & 1.02 & 5.39 \\
\hline Tannic acid & - & - & - & - & 5.50 & - & - & 7.48 & - \\
\hline Geraniol & 2.37 & - & 2.74 & - & - & - & 4.24 & - & 6.85 \\
\hline Quercetin & 6.25 & 6.20 & - & 6.22 & 6.21 & 6.48 & 6.49 & 6.23 & - \\
\hline Cinnamic acid & - & - & - & - & - & - & - & - & - \\
\hline
\end{tabular}



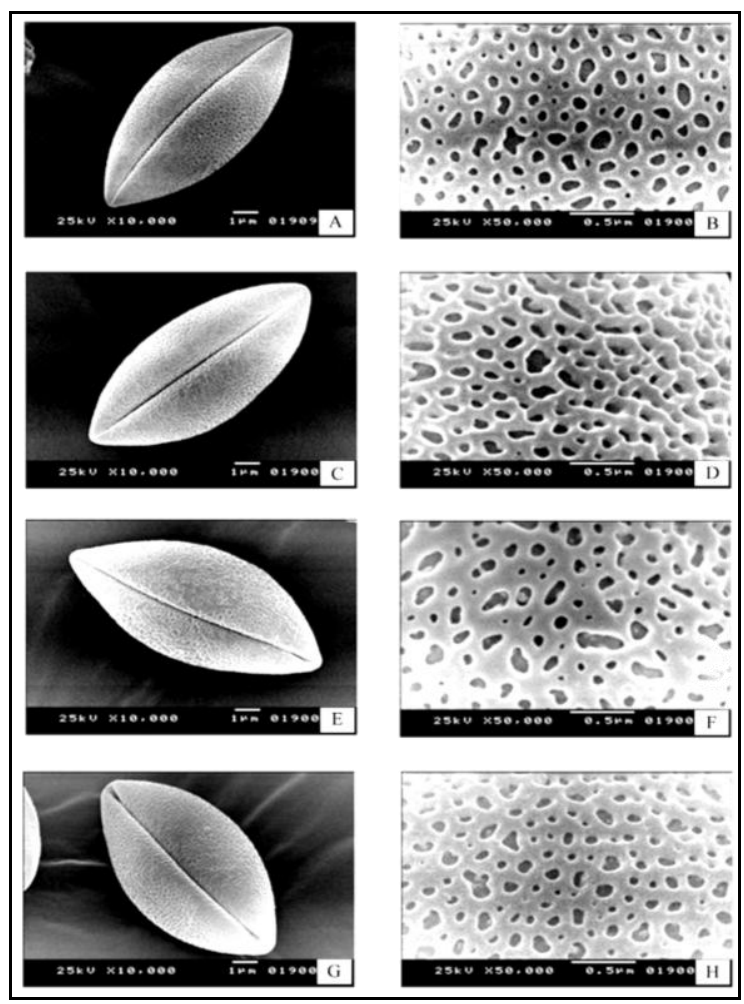

Fig. 1 Pollen shape and exine pattern of date palm cultivars: A, B, cultivar "1"; C, D, cultivar "2"; E, F, cultivar "3"; G, H, cultivar "4"

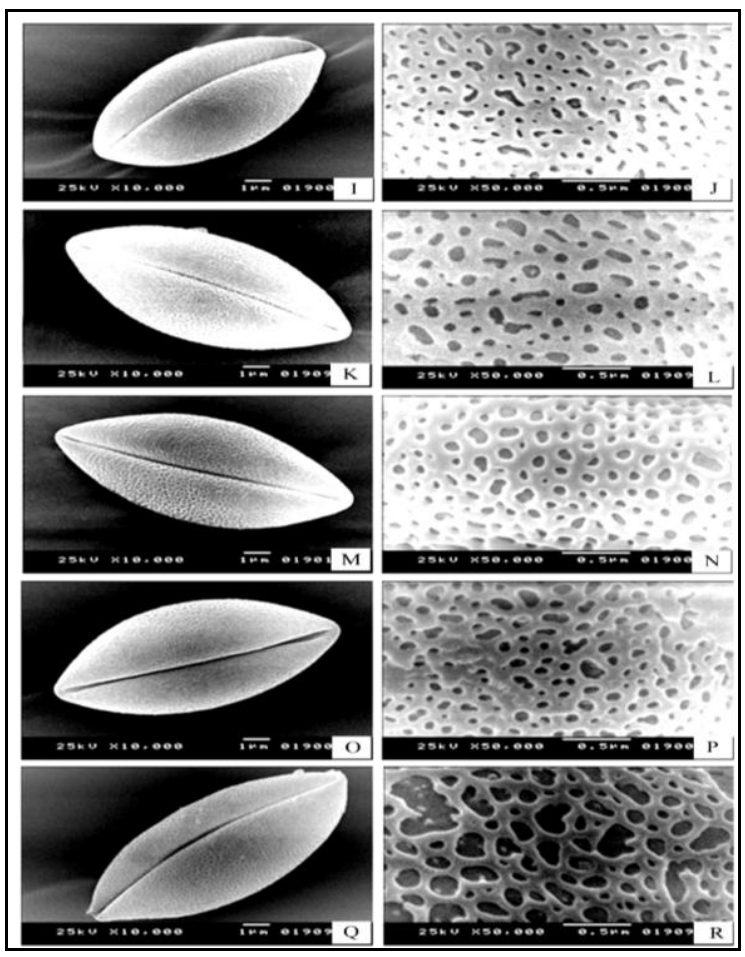

Fig. 2 Pollen shape and exine pattern of date palm cultivars: I, J, cultivar "5"; K, L, cultivar "6"; M, N, cultivar "7"; O, P, cultivar "8"; Q, R, cultivar 
"9"
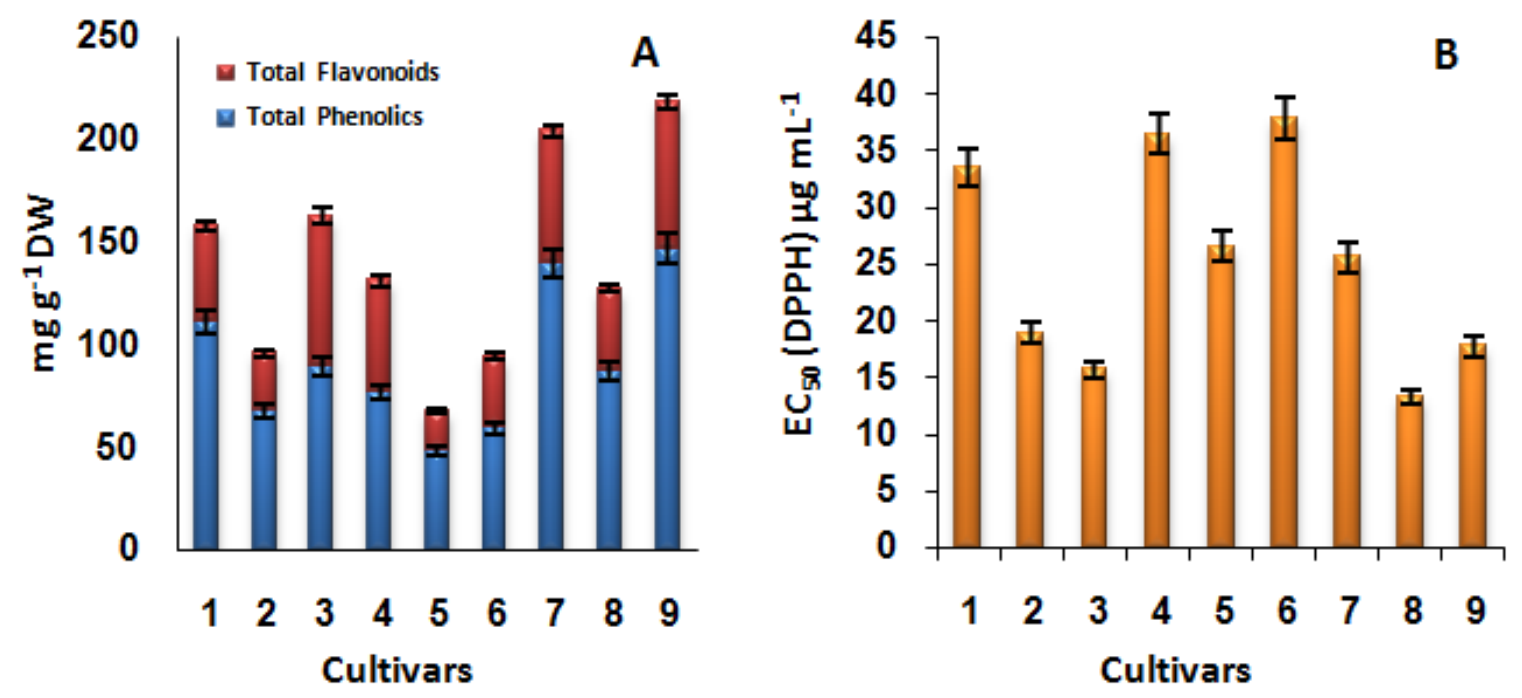

Fig. 3 Total phenolics and flavonoids content (A) and $\mathrm{EC}_{50}$ values of DPPH radical scavenging activity (B) of methanolic extracts of the nine pollen date palm cultivars, names of cultivars are in Table 1 . Mean value \pm standard error $(n=3)$
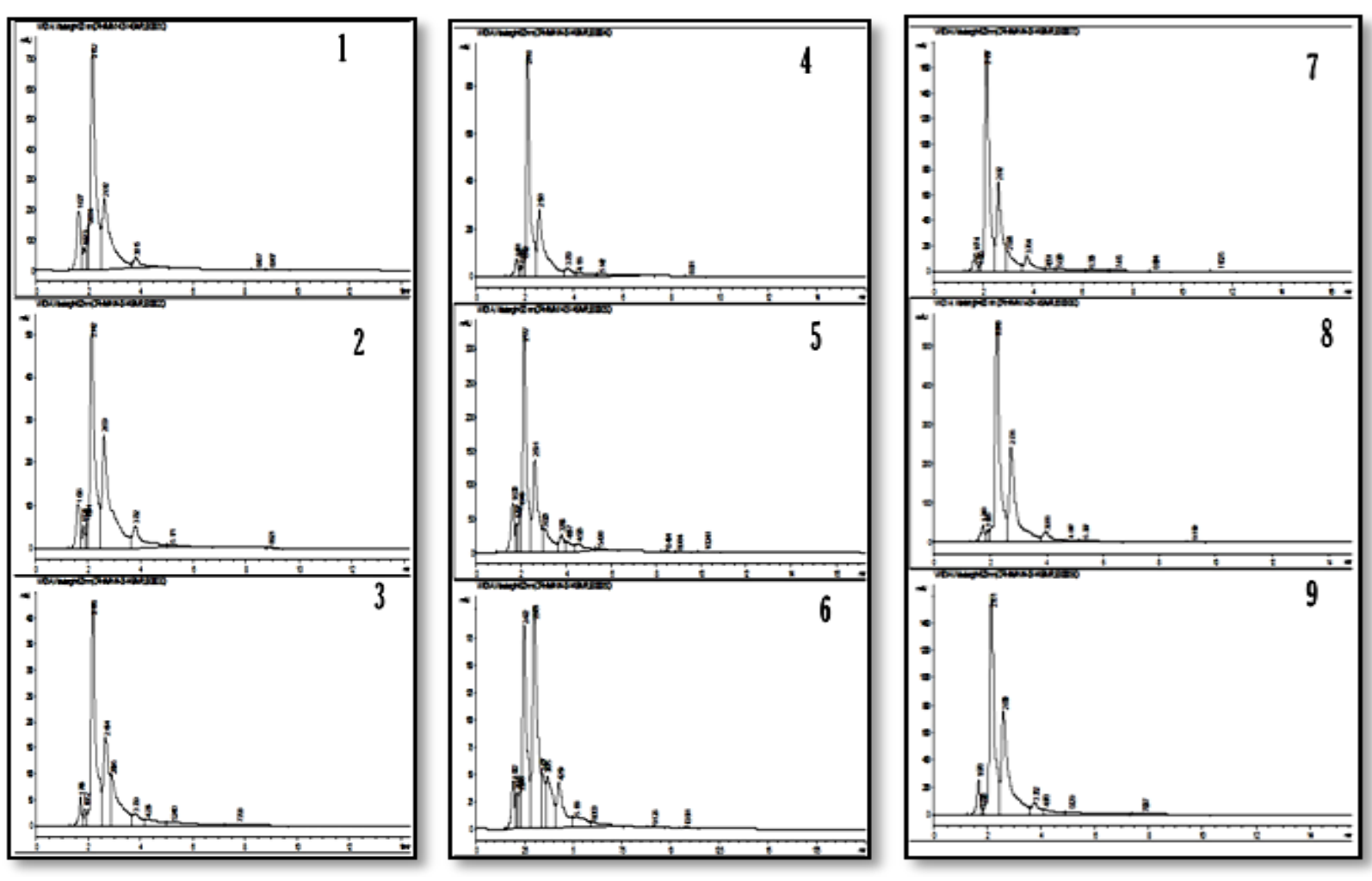

Fig. 4 HPLC chromatogram for methanolic extracts of the nine pollen cultivars, names of cultivars are in Table 1 
Compared with 14 reference standard phenolic and flavonoid compounds, the HPLC- analysis results for the methanolic extract of the studied pollen samples showed a noticeable valuation in the distribution of different phenolic and flavonoid compounds (Table 2 and Figure 4). Gallic acid, chlorogenic acid and caffeic acid were commonly detected in all pollen extracts. While 3, 5-dicaffeoyl quinic acid was only detected in pollen cultivar Succary, while, 2,5-dihydroxy benzoic acid, cinnamic acid are not detected in any of pollen samples. Geraniol only detected in cultivars Mabroom, Khadary, Safawy and Safry. However, 4, 5dicaffeoyl quinic acid was detected in all cultivars except Khalas. Rutin was commonly detected in all pollen samples except cultivar Mabroom. Serra Bonvehí et al., (2001), stated that rutin could be an indicator of the quality of bee pollen, which might reflect long periods of storage or excessive heating during the drying process. Quercetin was detected in all pollen samples except cultivars Khadary and Safry. However, tannic acid was only detected in the pollen extract of cultivar Khalas. Catechin is only detected in cultivars Maktumi and Khalas.

Generally, the phytochemical analyzes of the studied pollen grains, showed considerable antioxidant activity and a great diversity of phenolics and flavonoids. The present result, agreed with Pietta (2000) as well as Freire et al., (2012). They emphasized the significant role that the phenolics and flavonoids play in the antioxidant capacity of pollen. Moreover, the obtained data are consistent with the previous study of Abed El-Azim et al., (2015), who reported that the pollen of the date palm have six compounds which were identified as caffeic acid, gallic acid, coumaric acid, chlorogenic acid, catchin and quercetin. Additionally, many types of flavonoids have been identified in date pollen palm. Abbas and Ateya (2011) isolated five flavonoids compounds (rutin, luteolin-7-O-bD-glucoside, apigenin, isorhamnetin-3-Oglucoside and naringin for the first time from the pollen. Moreover, Daoud et al., (2015) found that the pollen of Tunisian date palm cultivars contain high concentrations of flavonoids, and four types of flavonoids which include quercitin, rutin, catechin and epicatechin. Recently, AL-Samarrai et al., (2017) found that Iraqi pollen date palm contain many types of flavonoids (lincoceric acid, chlorogenic acid, ferulic acid, naringin, apigenin-7-O-beta glycopyranoside, letulin and letulin-7-O-beta glycosides).

Pollen features joining with the phytochemical profile may provide a valuable additional tool of potential value in the characterization of the studied Saudi Arabian date palm cultivars. Moreover, the analysis of date palm pollen grains exhibited considerable phenolic and flavonoids content that displayed good antioxidant activities.

\section{References}

Abbas, A.F. and Ateya, A.M. 2011. Estradiol, esteriol, estrone and novel flavonids from date palm pollen. Aust. J. Basic Appl. Sci, 5(8): 606-614.

Abed El-Azim, M.H.M., El-Mesalamy, A.M.D., Yassin, F.A. and Khalil, S.A. 2015. Identification Phenolicand Biological Activities of Methanolic Extract of Date Palm Pollen (Phoenix dactylifera). J.Microb. Biochem. Technology, 7: 4750.

Almeida-Muradian, L.B., Pamplona, L.C., Coimbra, S. and Barth, O. 2005. Chemical composition and botanical evaluation of dried bee-pollen pellets. Journal of Food Composition and Analysis, 18: 105-111.

Al-Samarrai, R.R., AL- Samarrai, A.H. and ALSalihi, F.G. 2017. Identification of Flavonoids in Iraqi Date Palm Pollen by 
HPLC. Oriental Journal Of Chemistry, 33 (2): 985-988.

Bashah, M.A., Ali, M.A. and Farahat, F.A. 1997. Chemical composition of pollengrains of some date palm males grown in Riyadh, Saudi Arabia. Arab gulf journal scientific, 15(3): 783-803.

Basuny, A.M., Shaker, M. A. and Hanaa, M. S. 2013. Chemical analysis of olive and palm pollen: Antioxidant and antimicrobial activation properties. Wudpecker Journal of Food Technology, 1(2): 014-021.

Bishr, M. and Desoukey, S.Y. 2012. Comparative Study of the Nutritional Value of Four Types of Egyptian Palm Pollens. J. Pharmacy and Nutrition Sciences, 2: 50-56.

Czapecka, E., Mareczek, A. and Leja, M. 2005. Antioxidant activity of fresh and dry herbs of some Lamiaceae species, Food Chemistry, 93: 223-226.

Daoud, A., Malika, D., Bakari, S. and Gharsallah, N. 2015. Assessment of polyphenol composition, antioxidant and antimicrobial properties of various extracts of Date Palm Pollen (DPP) from two Tunisian cultivars. Arabian Journal of Chemistry, 7:2-14.

Elgindi, M.R., Singab, A.N., El-Taher, E.M. and Kassem, M. E. A. 2015. Comprehensive review of Phoenix (Arecaceae). Research Journal of Pharmaceutical, Biological and Chemical Sciences, 6(3): 966-74.

Eoin, L.N. 2016. Systematics: Blind dating.Nat Plants, 2(5), 16069.

Erdtman, G. 1952. Pollen morphology and plant taxonomy-angiosperms. Stockholm: Almqvist and Wiksell, pp 539.

Erdtman, G. 1969. Handbook of palynology. An introduction to the study of pollen grains and spores.486pp. Hafner Publishing Company. New York.

Farouk, A., Metwaly, A. and Mohsen, M. 2015. Chemical composition and antioxidant activity of Date Palm pollen grains (Phoenix dactylifera L. Palmae) essential oil for Siwe Cultivar Cultivated in Egypt.
Middle East Journal of Applied Sciences, 5(4): 945-949.

Freire, K.R.L., Lins, C. S.A., Dórea, C.M., Santos, A. R. F., Camara, A.C. and Silva, M.S.T. 2012. Palynological origin, phenolic content, and antioxidant properties of honeybee-collected pollen from Bahia. Brazil Molecules, 17: 16521664.

Harley, M.M. 1990. Occurrence of simple, tectate, monosulcate or trichotomosulcate pollen grains within the Palmae. Rev. Paleobot. Palynol., 64: 137-147.

Hassan, H.M. 2011. Chemical composition and nutritional value of palm pollen grains. Global Journal of biotechnology and biochemistry, 6(1): 1-7.

Kumazawa, S., Hamasaka, T. and Nakayama, T. 2004. Antioxidant activity of propolis of various geographic origins. Food Chemistry, 84: 329-339.

Martínez-Gómez, P., Sánchez-Pérez, R., Rubio, M. and Dicenta, F. 2005. Application of recent biotechnologies to Prunus tree crop.Genetic improvement.Cien. Inv. Agr., 32 (2):55-126.

Mohamed, R.A.N., Essam, D., Ezz, G.G. and Shaimaa, F. A. 2016. Comparison study among pollen grains of three date palm males cultivars Phoenix dactylifera L. J. Biol. Chem. Environ. Sci., 11 (3): 263275.

Morais, M., Moreira, L., Feás, X. and Estevinho, L.M. 2011. Honeybeecollected pollen from five Portuguese Natural Parks: Palynological origin, phenolic content, antioxidant properties and antimicrobial activity. Food and Chemical Toxicology, 49: 1096-1101.

Moreira, L., Dias, L.G., Pereira, J.A. and Estevinho, L. 2008. Antioxidant properties, total phenols and pollen analysis of propolis samples from Portugal. Food and Chemical Toxicology, 46: 3482-3485.

Najla, B., Rabea, G.T., Yamina, B. and Fatma, R. 2017. Studies on chemical composition and antimicrobial activities of bioactive molecules from date palm(phoenix 
dactylifera L.) pollens and seeds. African journal of Traditional, Complementary and alternative Medicines, 14(3):242-256.

Nikolić, D. and Milatović, D. 2016. Pollen morphology of some sweet cherry cultivars observed by scanning electron microscopy. Acta Hortic., 1139: 369-374.

Padda, M. and SandPicha, D.H. 2007. Methodology optimization for quantification of total phenolics and individual phenolic acids in sweetpotato (Ipomoea batatas L.) roots. Journal of Food Science, 72: 412-416.

Pietta, P.G. 2000. Flavonoids as antioxidants. J. Nat. Prod., 63:1035-1042.

Potter, S.M., Mitchell, A.J., Cowden, W.B., Sanni, L.A., Dinauer, M., De Haan, J.B., Krishna, K.L., Mruthunjaya, K., and Patel, J.A. 2010. Antioxidant and hepatoprotective potential of stem methanolic extract of Justicia gendarussa Burm. International Journal of Pharmacology, 6(2): 72-80.

Punt, W., Hoen, P.P., Blackmore, S., Nilsson, S. and Thomas, A.L. 2007. Glossary of pollen and spore terminology. Rev.Palaebot. Palynol., 143: 1-81.

Rashid, A.A., Anjum, P. and Roohi, A. 2017. pollen morphology of the subfamily coryphoideae -arecaceae (excluding tribe phoeniceae) from pakistan and kashmir. Pak. J. Bot., 49(2): 605-616.

Serra Bonvehí, J., SolivaTorrentó, M. and CentellesLorente, E. 2001. Evaluation of polyphenolic and flavonoid compounds in honeybee-collected pollen produced in. Spain. J. Agric. Food Chem., 49: 18481853.

Simozrag, A., Chala A., Djerouni, A. and Bentchikou, M.E. 2016. Phenotypic diversity of date palm cultivars (Phoenix dactylifera L.) from Algeria. Gayana Bot., 73(1): 42-53.

Singh, R.P., Murthy, K.N.C. and Jayaprakasha, G.K. 2002. Studies on antioxidant activity of pomegranate (Punicagr anatum) peel and seed extracts using in vitro models. J. Agric Food Chem., 50:81-86.

Soliman, S.S. and Al-Obeed, R.S. 2013. Investigations on the pollen morphology of some date palm males (Phoenix dactylifera L.) in Saudi Arabia. Australian Journal of Crop Science, 7(9): 1355-1360.

Tulipani, S., Mezzetti, B., Capocasa, F., Bompadre, S., Beekwilder, J., De Vos, C.H.R., Capanoglu E., Bovy, A. and Battino, M. 2008. Antioxidants, Phenolic compounds and nutritional quality of different Strawberry genotypes. Journal of Agricultural Food Chemistry, 56: 696704.

Tura, D. and Robards, K.J. 2002. Sample handling strategies for the determination of biophenols in food and plants. Journal of Chromatography, 973:71-93.

Wolfe, K., Wu, X. and Liu, R.H. 2003. Antioxidant activity of apple peels. Journal of Agriculture and Food Chemistry, 51: 609-614.

Zaid, A. and De Wet, P.F. 1999. Botanical and Systematic description of the date palm. In: A. Zaid (ed.), Date Palm Cultivation. pp. 1-28. FAO, Rome.

Zou, Y., Lu. Y. and Wei, D. 2004. Antioxidant activity of a flavonoid-rich extract of Hypericum perforatum L. in vitro. Journal of Agricultural and Food Chemistry, 52: 5032-5.

\section{How to cite this article:}

Hanan Mahmoud Abou-Zeid, Mona Adel Shiha and Azza Ahmed Shehata. 2019. Comparative Study of Pollen Grains Morphology and Phytochemical Constituents of Some Saudi Arabian Date Palm (Phoenix dactylifera L.) Cultivars. Int.J.Curr.Microbiol.App.Sci. 8(07): 2800-2809. doi: https://doi.org/10.20546/ijcmas.2019.807.350 